\title{
Pumiceous rhyolitic peperite in ancient submarine volcanic successions
}

\author{
Cathryn C. Gifkins ${ }^{\mathrm{a}, *}$, Jocelyn McPhie ${ }^{\mathrm{a}}$, Rodney L. Allen ${ }^{\mathrm{b}}$ \\ ${ }^{a}$ Centre for Ore Deposit Research, School of Earth Sciences, University of Tasmania, G.P.O. Box 252-79, Hobart, TAS 7001, \\ Australia \\ b Volcanic Resources Ltd., Guldgatan, 93632 Boliden, Sweden
}

Received 7 April 2000; accepted 12 September 2000

\begin{abstract}
Pumiceous peperite is associated with a rhyolitic sill that intruded wet, unconsolidated, submarine stratified pumice breccia in the Cambrian Mount Read Volcanics, Australia. Other examples of pumiceous peperite described in this paper occur at the pumiceous base of a rhyolitic lava and the margins of a rhyolitic cryptodome complex in the Miocene Green Tuff Belt, Japan. Intervals of pumiceous peperite are thin $(<15 \mathrm{~m})$, laterally discontinuous, massive, poorly sorted and the clast-to-matrix ratio varies significantly over short distances. They are composed of feldsparphyric tube pumice clasts and domains of clastic sediment that include stratified pumice breccia, pumiceous siltstone and bioturbated mudstone. The sediment domains may be massive or may display relic depositional structures. Sediment adjacent to pumice clasts is silicified, possibly reflecting induration on contact with hot pumice. Pumiceous peperite has gradational contacts with in situ and clast-rotated pumiceous hyaloclastite and coherent pumiceous rhyolite. Gradational relationships between pumiceous peperite and coherent pumiceous rhyolite, pumice clasts with chilled margins and curviplanar surfaces, and abundant jigsaw-fit texture imply that quench fragmentation and autobrecciation were the dominant mechanisms of clast formation. The formation of pumiceous peperite is favoured by a combination of low confining pressure and delayed quenching allowing vesiculation. Pumiceous peperite may easily be misinterpreted or overlooked as it resembles other pumice-rich facies that are common in submarine volcanic successions. The correct identification of pumiceous peperite can provide evidence to constrain the timing of intrusive episodes in volcanic successions. (c) 2002 Elsevier Science B.V. All rights reserved.
\end{abstract}

Keywords: pumiceous peperite; pumice breccia; rhyolite; submarine volcanic succession; Mount Read Volcanics; Green Tuff Belt

\section{Introduction}

Although pumiceous lavas are common in both subaerial (Fink, 1983; Fink and Manley, 1987;

\footnotetext{
* Corresponding author. Tel.: +61-3-6226-2481; Fax: +61-3-6223-2547.

E-mail address: cgifkins@utas.edu.au (C.C. Gifkins).
}

Kano et al., 1991) and submarine settings (Cas et al., 1990; Kurokawa, 1991; Yamagishi, 1991; Gifkins et al., 1996; Scutter and Cas, 1998; Waters and Binns, 1998), the potential for shallow intrusions to be pumiceous is not widely appreciated. Pumice clasts are more typically associated with subaerial or shallow subaqueous explosive eruptions. It is clear that both explosive and effusive eruptions can generate deposits of coarse 
clastic pumice clasts (pumice breccia). We have identified an additional variety of pumice breccia (pumiceous peperite) produced by disintegration of pumiceous intrusions emplaced into unconsolidated probably wet sediment.

We describe three examples of pumiceous peperite associated with shallow rhyolitic intrusions and the base of a rhyolitic lava dome. These examples occur at two locations: the Cambrian Mount Read Volcanics in western Tasmania, Australia, and the Miocene Green Tuff Belt in the Hokuroku Basin, Japan. They involve pumiceous to non-vesicular rhyolite enveloped by in situ pumiceous hyaloclastite and pumiceous peperite. For each example the textures, facies and the distribution of the rhyolite, hyaloclastite, pumiceous peperite and the host sediment are described.

Pumiceous peperite can be texturally similar to various pyroclastic and effusive pumice-rich facies. Specific criteria that discriminate pumiceous peperite from other pumice-rich facies are considered. In general, the positive identification of peperite requires evidence that the host sediment was unconsolidated and that the igneous component was hot at the time of fragmentation and mingling. Pumiceous peperite can be especially difficult to recognise because the igneous component (pumice) is typically almost entirely glassy and porous, and undergoes dramatic textural changes during diagenesis. We suggest that the paucity of examples of pumiceous peperite in the geological literature partly reflects the difficulty of identifying this facies. Identification of peperite is of critical importance in facies architecture and stratigraphic research, providing constraints on the age relationships and timing of intrusive episodes.

\section{Pumiceous peperite associated with a syn-volcanic sill in the Mount Read Volcanics}

\subsection{Geological setting}

Pumiceous peperite is associated with felsic in- trusions in the northern Central Volcanic Complex, one of the four main lithostratigraphic units in the Cambrian Mount Read Volcanics in western Tasmania, Australia (Fig. 1). The Mount Read Volcanics crop out in a $200 \times 20 \mathrm{~km}$ area and are dominated by submarine, calc-alkaline volcanic and sedimentary rocks (Corbett and Lees, 1987; Corbett, 1992). The lithostratigraphic units comprise compositionally and texturally diverse volcanic and non-volcanic sedimentary facies. The volcanic rocks are predominantly rhyolite and dacite with locally abundant andesite and basalt (Crawford et al., 1992). The lithostratigraphy of the Mount Read Volcanics is disrupted by a major Cambrian fault zone, the Henty Fault (Fig. 1) (Berry, 1989), and the succession has been faulted and folded mainly during the Early to Middle Devonian (Corbett and Lees, 1987; Crawford and Berry, 1992). Regional metamorphism to greenschist facies accompanied Devonian deformation (Green et al., 1981; Walshe and Solomon, 1981; Corbett and Solomon, 1989). The Mount Read Volcanics host a number of volcanic-hosted massive sulphide (VHMS) deposits at Hellyer, Que River, Rosebery, Hercules and Mount Lyell (Fig. 1) (Corbett, 1992).

North of the Henty Fault, the Central Volcanic Complex is dominated by feldspar-phyric rhyolitic and dacitic lavas, syn-volcanic intrusions and syneruptive pumiceous volcaniclastic facies (Fig. 2) (Braithwaite, 1974; Corbett and Lees, 1987; Lees, 1987; Corbett and Solomon, 1989; Allen and Cas, 1990; Allen and Hunns, 1990; Allen, 1994a,b). Bedforms and textures within the volcaniclastic units are consistent with deposition from turbidity currents, debris flows and suspension in a below-wave-base submarine environment.

The rhyolitic lavas and intrusions are commonly highly vesicular or pumiceous at the margins and associated with pumiceous autobreccia, hyaloclastite and peperite (Gifkins et al., 1996, 1998). The example of pumiceous peperite presented here comes from drill core through the footwall to the Rosebery-Hercules VHMS, near

Fig. 1. Geology of the Mount Read Volcanics, western Tasmania, Australia. The map shows the distribution of the main lithological associations in the Mount Read Volcanics including the Central Volcanic Complex. An example of pumiceous peperite is described from drill hole KP303 south of the Rosebery VHMS deposit. Geology modified after Corbett (1992). 


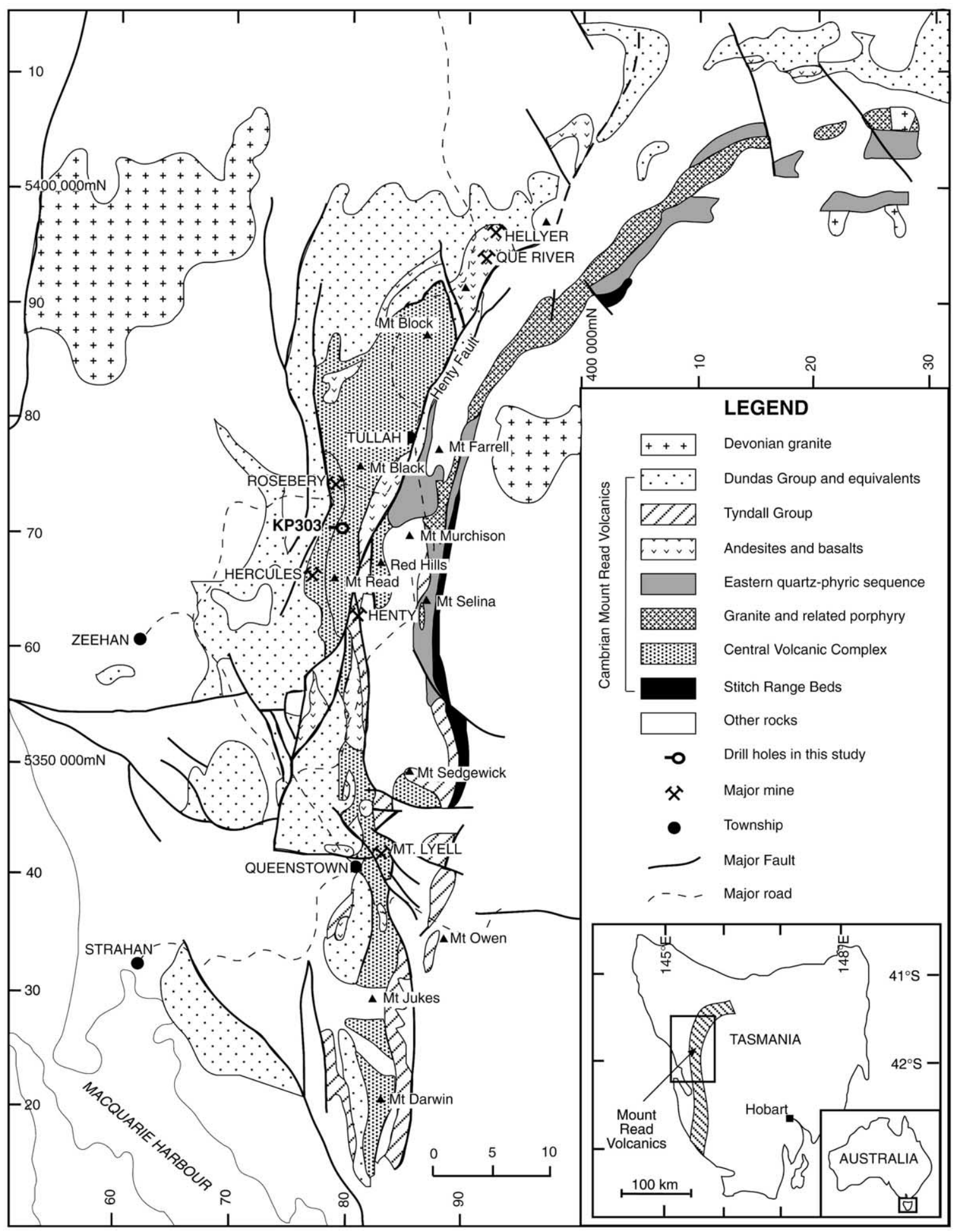




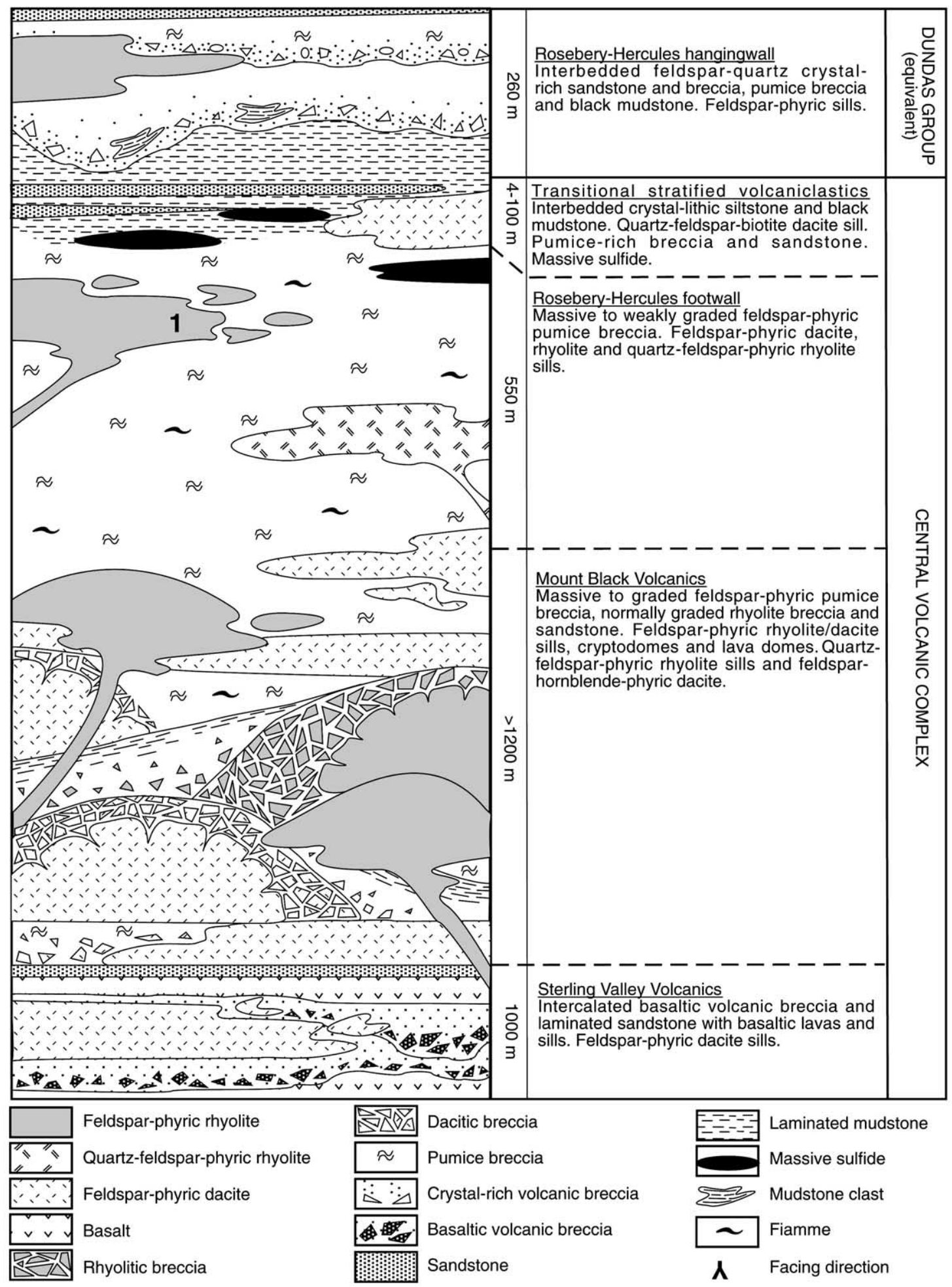




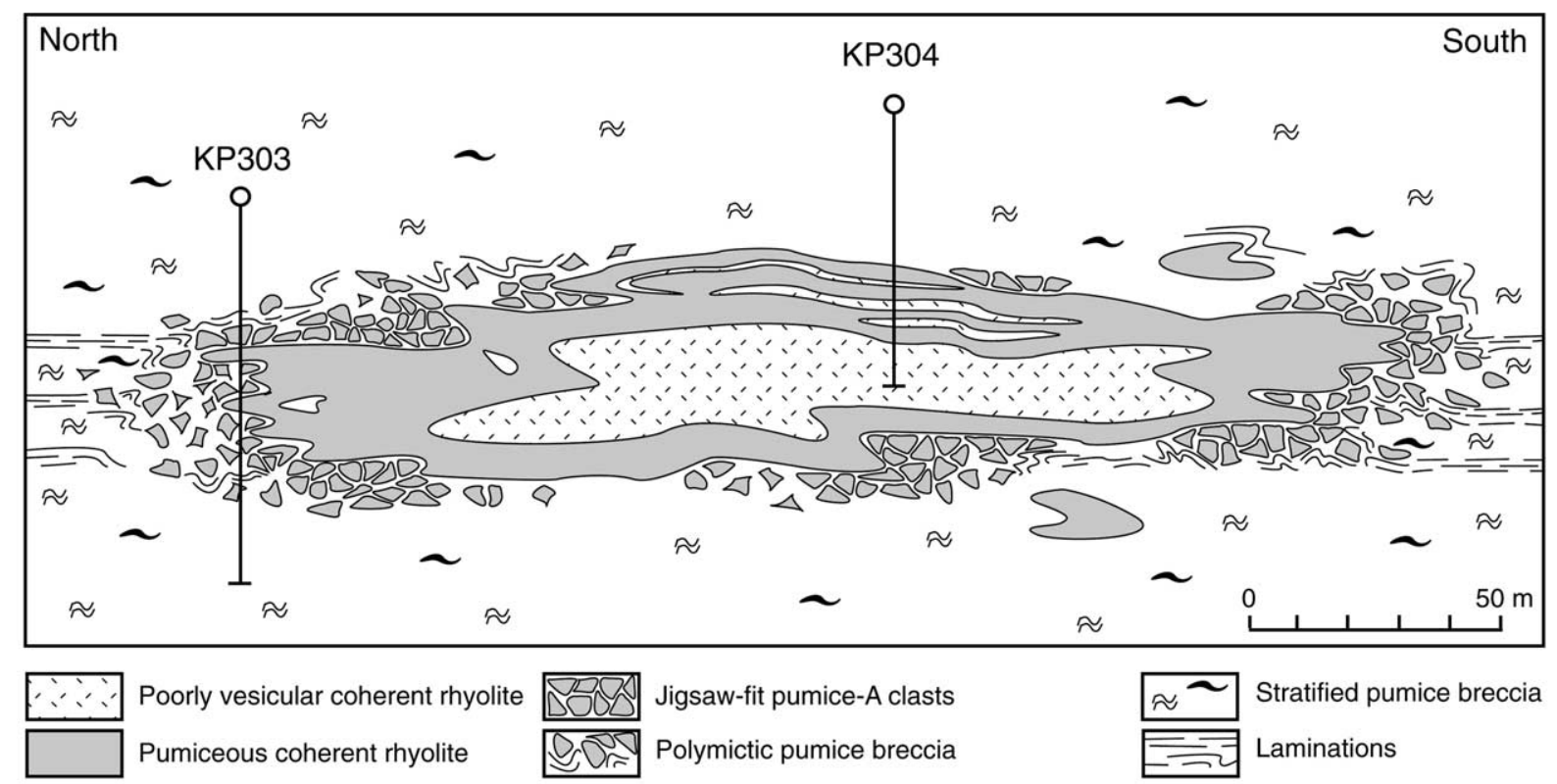

Fig. 3. Schematic diagram of the distribution of coherent poorly vesicular, rhyolite, coherent pumiceous rhyolite and polymictic pumice breccia (interpreted to be pumiceous peperite) in stratified pumice breccia from the Rosebery footwall, near Koonya. These facies associations are interpreted to represent a syn-volcanic sill that has intruded unconsolidated pumice breccia.

Koonya (Fig. 2). Facies relationships and the stratigraphic context of the pumiceous peperite are well constrained by detailed core logging of closely spaced drill holes in the area.

The volcanic facies at Koonya are dominated by normally graded, thick $(60 \mathrm{~m})$ stratified pumice breccias intruded by pumiceous and weakly vesicular rhyolite. Pumiceous peperite at the margin of a rhyolitic sill is preserved in drill hole KP303 (Figs. 3 and 4). Pumiceous rhyolite varies laterally from being a single 150 -m-thick unit of coherent rhyolite with a pumiceous upper contact (in KP304) to several thin $(<5 \mathrm{~m})$ intervals of coherent pumiceous rhyolite separated by polymictic pumice breccia (interpreted to be pumiceous peperite) and stratified pumice breccia (in KP303) (Fig. 3). Pumiceous rhyolite clasts derived from the pumiceous rhyolite are texturally very similar to pumice clasts in the stratified pumice breccia, making it difficult to distinguish the two types.

\subsection{Stratified pumice breccia}

Stratified feldspar-phyric pumice breccia $(562-$ $570 \mathrm{~m}$; Fig. 4) occurs in beds up to $60 \mathrm{~m}$ thick. Pumice clasts are moderately well sorted, and beds are normally graded with coarse bases (6 $\mathrm{cm}$ clasts) and laminated sandstone-siltstone tops.

Stratified pumice breccia is composed of feldspar-phyric pumice clasts $(70 \%, 1 \mathrm{~mm}$ to $3 \mathrm{~cm})$, plagioclase crystals $(15 \%, 1 \mathrm{~mm})$, shards $(15 \%, 0.5$ $\mathrm{mm}$ ) and dense lithic clasts (approximately $1 \%$, averaging $5 \mathrm{~mm}$ ). Plagioclase crystals have been variably altered to albite, sericite and carbonate. Vesicles in the pumice clasts are dominantly tube vesicles although round vesicles are also pre-

Fig. 2. Schematic diagram depicting the stratigraphy and facies architecture of the Central Volcanic Complex in the RoseberyHercules area. 1, pumiceous peperite associated with a pumiceous rhyolitic sill in the Rosebery footwall near Koonya. Fiamme refers to altered, lenticular, juvenile volcanic fragments that define a bedding parallel foliation. Stratigraphy modified after Allen (1994a) and Gifkins (unpublished data). 


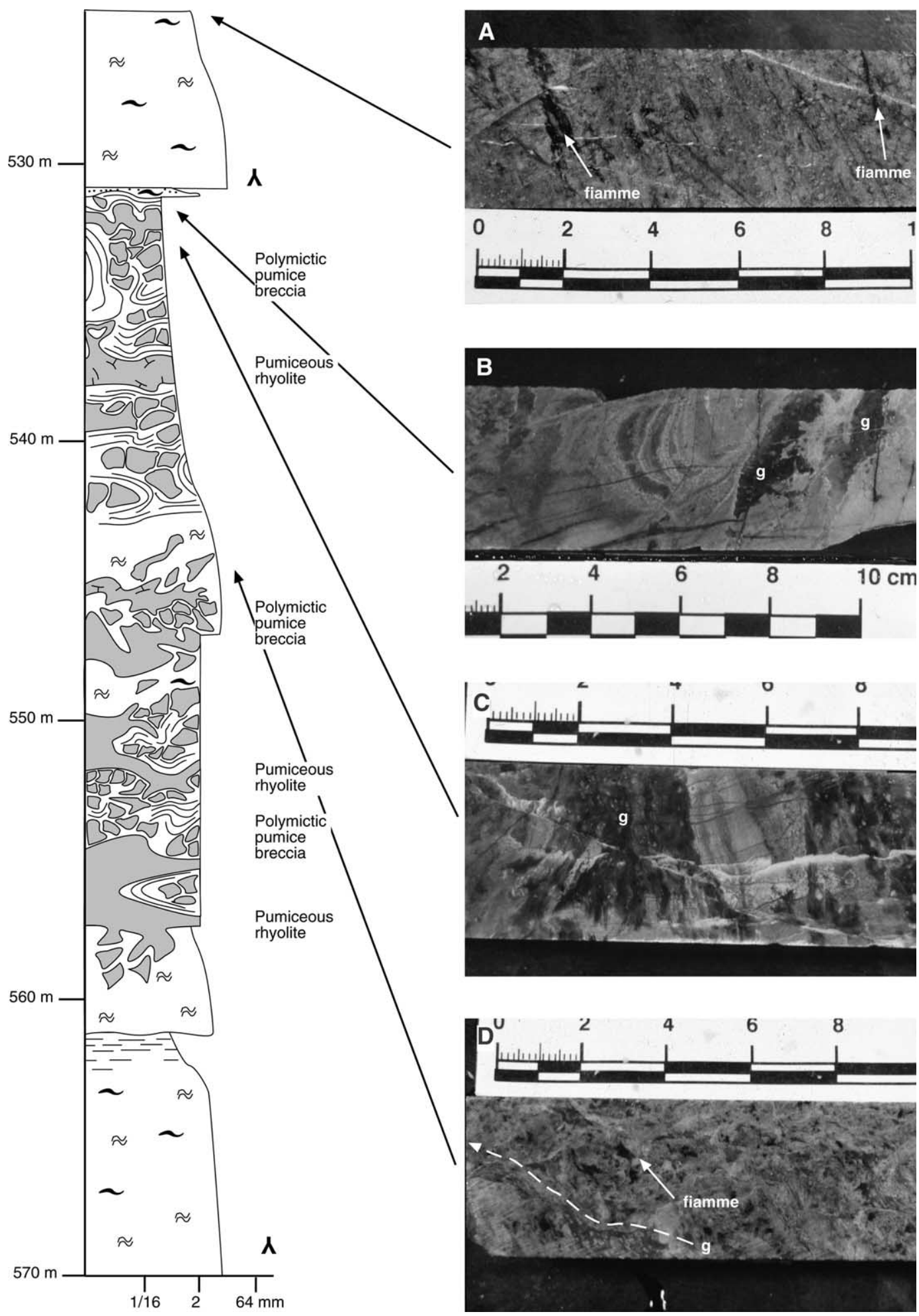


served. Clasts are both blocky and ragged in shape and show varying degrees of compaction. Uncompacted clasts are typically altered to albite and disseminated hematite. Strongly compacted clasts (fiamme) are intensely sericite- or chloritesericite-altered, elongate parallel to bedding $\left(S_{0}\right)$ and have feathery terminations. The fiamme are commonly transposed into the steeply dipping regional cleavage $\left(\mathrm{S}_{2}\right)$ (Fig. 5A). Rare lithic clasts include feldspar-phyric spherulitic, perlitic and amygdaloidal rhyolite and dacite. The siltstone tops are dominated by originally glassy shards, pumice clasts, plagioclase crystals and rare lithic clasts. Laminae are planar, even thickness and continuous with sharp boundaries and internal grading.

\subsection{Pumiceous rhyolite}

Intervals of rhyolite in the Koonya area vary from 150 to $3 \mathrm{~m}$ in thickness, extend laterally for a minimum of $100 \mathrm{~m}$ (Fig. 3) and are conformable with bedding in the stratified pumice breccia. The rhyolite facies is feldspar-phyric containing 3\%, $2 \mathrm{~mm}$ plagioclase phenocrysts in a fine-grained groundmass of feldspar-quartz-sericite. The plagioclase phenocrysts are partially altered to albite and sericite. The groundmass varies texturally from non-vesicular to vesicular with round and tube vesicles (pumiceous rhyolite). The vesicles are outlined by thin films of sericite or hematite and filled with albite.

\subsection{Polymictic pumice breccia}

Intervals of the polymictic pumice breccia facies are up to $15 \mathrm{~m}$ thick and have gradational contacts with pumiceous rhyolite and stratified pumice breccia (533-559 m, Fig. 4). The polymictic pumice breccia is composed of plagioclase-phyric pumice clasts, green plagioclase-phyric clasts in a matrix of feldspar crystal fragments and undeformed bubble wall shards. There are two different plagioclase-phyric pumice clast populations: pumice-A and pumice-B.

Pumice-A clasts are uncompacted, plagioclasephyric $(3 \%, 1.5-2 \mathrm{~mm})$ tube pumice. They are commonly pale pink or white with a pink rim. Clasts of pumice-A vary from $<1 \mathrm{~mm}$ to $5 \mathrm{~cm}$ in length and in shape from blocky to fluidal. The blocky clasts are equant or elongate parallel to the tube vesicles. They have delicate feathery edges perpendicular to the tubes and delicately scalloped surfaces parallel to the tubes (Fig. 5B,D). The plagioclase crystals occur in glomerocrysts surrounded by round vesicles (Fig. 5C), and have been altered to albite, sericite, carbonate or microcrystalline quartz. The originally glassy vesicle walls are also altered to albite and sericite. Thin films of sericite and/or hematite line the vesicle walls and the vesicles are filled with albite (Fig. 5C). Many clasts contain fine fractures parallel to the tube vesicles that are filled with submillimetre quartz and feldspar (Fig. 5B).

Pumice-B clasts are phenocryst-rich, containing $10-20 \%, 1-\mathrm{mm}$ plagioclase phenocrysts. Clasts of pumice-B are green, elongate with ragged edges, and are between $0.5 \mathrm{~mm}$ and $6 \mathrm{~cm}$ in length. Pumice-B clasts are variably compacted and aligned parallel to bedding in the adjacent stratified pumice breccia. The original plagioclase phenocrysts have been replaced by albite, sericite and carbonate. The originally glassy vesicle walls are composed of albite. Compacted pumice clasts are commonly sericite- and/or chlorite-altered.

Green feldspar-phyric clasts contain 3-5\%, 1.5$\mathrm{mm}$ plagioclase phenocrysts in a groundmass of fine-grained massive chlorite and sericite. The green feldspar-phyric clasts are up to $6 \mathrm{~cm}$ in length and have a variety of shapes: blocky and equant; delicately fluidal; wispy and elongate. The blocky clasts have feathery margins (Fig.

Fig. 4. Graphic log of diamond drill hole KP303 where it intersects intervals of pumiceous peperite (polymictic pumice breccia) and coherent pumiceous rhyolite. Refer to Fig. 3 for legend. (A) Stratified pumice breccia with chlorite-altered fiamme. (B) Polymictic pumice breccia containing irregular green feldspar-phyric clasts $(\mathrm{g})$ and deformed laminae. (C) Large green feldspar-phyric clast (g) with feathery terminations, surrounded by pale grey, silicified, laminated siltstone. (D) Interconnected green feldspar-phyric clasts $(\mathrm{g})$ dispersed in pumice-B clasts and fiamme. 

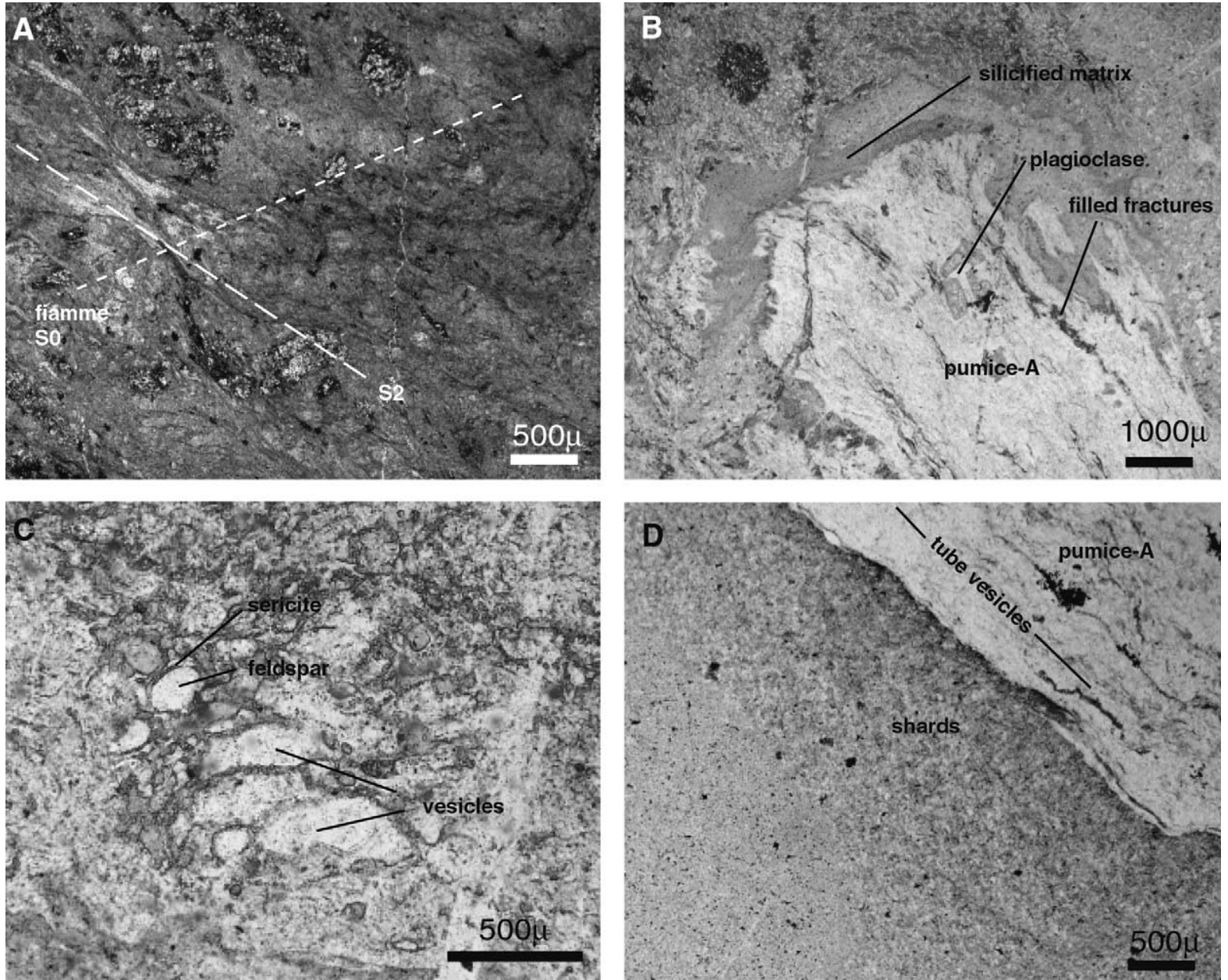

Fig. 5. (A) Photomicrograph (ppl) of stratified pumice breccia. Sericite fiamme are transposed into the regional cleavage $\left(\mathrm{S}_{2}\right)$. $(\mathrm{B}-$ D) are photomicrographs (ppl) of pumice-A clasts in polymictic pumice breccia. (B) Uncompacted plagioclase-phyric pumice-A clast with feathery edges perpendicular to the tube vesicles. Fractures in the pumice-A clast are filled with fine quartz and feldspar and the clast is surrounded by fine silicified matrix. (C) Round vesicles preserved in a pumice-A clast contain thin films of sericite and are feldspar-filled. (D) Uncompacted silicified shards are preserved in the matrix adjacent to a pumice-A clast. Further from the clast shards are variably compacted and altered to feldspar, sericite and chlorite. The pumice-A clast has scalloped margins parallel to the tube vesicles.

4C) and some preserve tube vesicles that are filled with albite. The fluidal clasts are commonly interconnected and have random orientations (Fig. 4D). The elongate clasts are aligned parallel to bedding in the stratified pumice breccia.

The polymictic pumice breccia is poorly sorted, varying from clast-supported to matrix-supported. Intervals of polymictic pumice breccia are massive; however, locally discontinuous domains of the matrix are laminated (Fig. 4B). Lam- inae are deformed into convolute folds. The proportions of pumice-A clasts, pumice-B clasts and green feldspar-phyric clasts vary considerably in intervals of polymictic pumice breccia. Locally, groups of pumice-A clasts have jigsaw-fit texture either with or without fine-grained matrix between the clasts. In domains of jigsaw-fit pumice-A clasts, the tube vesicles in adjacent clasts are parallel. Elsewhere pumice-A clasts and green feldspar-phyric clasts are scattered among clasts of 
pumice- $\mathrm{B}$, shards and feldspar crystal fragments. Pumice-B clasts and matrix (shards and feldspar crystal fragments) immediately surrounding (within $2-5 \mathrm{~mm}$ ) pumice-A clasts and green plagioclase-phyric clasts are silicified and uncompacted (Fig. 5D).

\subsection{Facies geometry and relationships}

The distribution and contact relationships among the stratified pumice breccia, pumiceous rhyolite and polymictic pumice breccia are complex (Figs. 3 and 4). Intervals of coherent pumiceous rhyolite have sharp to gradational lower and upper contacts that are locally disconformable with bedding. Irregular lobes and stringers of pumiceous rhyolite extend up to $50 \mathrm{~cm}$ into the surrounding stratified pumice breccia or polymictic pumice breccia. Commonly there is a gradational contact from coherent pumiceous rhyolite to jigsaw-fit blocky clasts of pumice, to polymictic pumice breccia. Near the contact between the pumiceous rhyolite and polymictic pumice breccia, clasts of pumice-A dominate the polymictic pumice breccia (Fig. 3). Areas of jigsaw-fit pumice-A clasts occur with or without silicified matrix. With increasing distance (between $50 \mathrm{~cm}$ and $5 \mathrm{~m}$ ) from the contact with the pumiceous rhyolite, the polymictic pumice breccia is dominated by pumice-B clasts, with isolated pumice-A and green feldspar-phyric clasts. This in turn grades into stratified pumice breccia.

Contact geometries between the stratified pumice breccia and polymictic pumice breccia are different in the finer tops versus the coarser bases of the stratified pumice breccia. Contacts between the siltstone top of pumice breccia beds and polymictic pumice breccia are irregular and laminae in the siltstone are commonly distorted or absent within $10 \mathrm{~cm}$ of the contact. Immediately adjacent to the contact, the polymictic pumice breccia is composed of poorly sorted pumice-A clasts, finegrained $(<2 \mathrm{~mm})$ pumice-B clasts, feldspar crystal fragments and shards. The polymictic pumice breccia contains isolated domains of siltstone with convolute and disrupted laminae. Contacts between coarser-grained pumice breccia and polymictic pumice breccia are very subtle and grada- tional, because pumice clasts in the stratified pumice breccia are texturally identical to pumice-B clasts. Thus contacts are implied by the presence of pumice-A clasts.

\subsection{Interpretation}

The pumiceous rhyolite, in situ jigsaw-fit pumice-A clasts at the margins of the rhyolite and pumice-A clasts in the polymictic pumice breccia are mineralogically and texturally identical. Gradational contacts among coherent pumiceous rhyolite, in situ jigsaw-fit pumice-A clasts and polymictic pumice breccia, and the similar phenocryst assemblages are consistent with the pumiceA clasts being derived from the pumiceous rhyolite. The presence of jigsaw-fit pumice-A clasts in the polymictic pumice breccia facies indicates that the clasts formed by in situ fragmentation. The curviplanar or scalloped surfaces on the long axis of some of the pumice-A clasts are consistent with brittle fragmentation, most likely involving the propagation and interconnection of thermal contraction cracks during quenching of pumiceous rhyolite (cf. Pichler, 1965; Yamagishi, 1987; Kano et al., 1996). Furthermore, pink feldspar-altered rims on pumice-A clasts may reflect fine chilled margins.

Pumice-A clasts and the green feldspar-phyric clasts in the polymictic pumice breccia are also mineralogically similar, the main difference being that pumice-A clasts contain well defined tube vesicles whereas the green feldspar-phyric clasts are now commonly structureless. The rare preservation of feldspar-filled tube vesicles and the alignment of elongate green feldspar-phyric clasts parallel to bedding in the stratified pumice breccia suggest that the green feldspar-phyric clasts are altered and variably compacted pumice-A clasts.

Pumice-B clasts and pumice clasts in the stratified pumice breccia are similar, both being phenocryst-rich tube pumice with approximately $15 \%, 1-\mathrm{mm}$ plagioclase phenocrysts. The stratified pumice breccia facies is composed of finely fragmented pumice clasts, shards and crystal fragments. These components are interpreted to be juvenile pyroclasts produced by an explosive sili- 
cic eruption. The thick and extensive beds indicate derivation from a large-volume eruption(s) (Allen and Cas, 1990). The angularity of the pumice clasts, preservation of shards, absence of non-juvenile clasts and mass-flow bedforms indicate rapid supply and deposition of these components, and that this facies is syn-eruptive.

The polymictic pumice breccia is thus composed of two pumice clast populations, one derived from the pumiceous rhyolite and the other derived from explosive eruptions that also supplied the stratified pumice breccia. The gradation from close-packed jigsaw-fit pumice-A clasts to pumice-A clasts dispersed in stratified pumice breccia dominated by pumice-B clasts and shards, implies that mixing of pumice-A clasts with the stratified pumice breccia occurred in situ and did not involve significant transport of either component.

Pumice-B clasts and shards are uncompacted in the zones of silicification surrounding pumice-A clasts, whereas pumice-B clasts elsewhere show varying degrees of compaction, suggesting that silicification took place prior to compaction. One possibility is that pumice-A clasts were hot, and locally baked or indurated pumice-B clasts and shards.

The disruption of laminae in the siltstone tops of the stratified pumice breccia both at the contacts with pumiceous rhyolite and in domains within the polymictic pumice breccia indicates that the stratified pumice breccia was unconsolidated and probably wet at the time of mixing. Local homogenisation of this nature may be the result of fluidisation and dynamic mixing of the wet unconsolidated sediment and the pumiceous rhyolite (Kokelaar, 1982).

In situ fragmentation of pumice-A clasts, interfingering relationships among the pumiceous rhyolite and pumice breccia facies, and local induration of the stratified pumice breccia are all consistent with the interpretation that the polymictic pumice breccia is pumiceous peperite. Pumiceous peperite was generated at both the top and bottom contacts of the pumiceous rhyolite. The irregular upper contacts, presence of peperite and conformable geometry of the rhyolite at Koonya suggest that it is a shallow syn-vol- canic sill emplaced into wet unconsolidated pumice breccia (Fig. 3).

\section{Pumiceous peperite and hyaloclastite associated with a lava dome in the Green Tuff Belt}

\subsection{Geological setting}

Pumiceous peperite is associated with the base of a pumiceous rhyolite lava dome emplaced onto siltstone in the Nishikurosawa Formation in the Hokuroku District of the Green Tuff Belt, northern Honshu, Japan (Fig. 6). The Middle Miocene Nishikurosawa Formation hosts Kuroko mineralisation within the Hokuroku Basin and is conformably overlain by the Onnagawa Formation (Figs. 6 and 7) (Nakajima, 1988). The Nishikurosawa and Onnagawa Formations comprise interbedded volcanic and sedimentary rocks (Nakajima, 1988). Volcanic facies in the Nishikurosawa and Onnagawa Formations are bimodal and consist of tholeiitic basalt and calc-alkaline rhyolite (Dudas et al., 1983; Urabe, 1987). Rhyolites are commonly referred to as dacites in the Kuroko literature (Ohmoto and Takahashi, 1983; Nakajima, 1988). The Green Tuff Belt has undergone extensive diagenetic alteration, local hydrothermal alteration and minor deformation (Utada, 1970; Tanimura et al., 1983). Generally the stratigraphy has a gentle dip with open, N-S-trending folds (Tanimura et al., 1983).

Depositional structures (graded beds, planar laminae and cross-bedding) in pumiceous sandstone and siltstone, and the presence of thick intervals of mudstone and foraminifera, constrain the depositional setting during the Nishikurosawa and Onnagawa Formations to a depth of 2000 $3000 \mathrm{~m}$ (Guber and Merill, 1983).

Pumiceous peperite and hyaloclastite were recognised in drill hole J6, southwest of the Fukazawa mine in the central Hokuroku Basin (Figs. 6 and 8). Here the Nishikurosawa Formation comprises intercalated basaltic lava, bomb breccia, volcanic breccia and mudstone that are conformably overlain by rhyolitic lava, lithic-pumice breccia, sandstone and minor mudstone (Fig. 7) (Tanimura et al., 1983). 


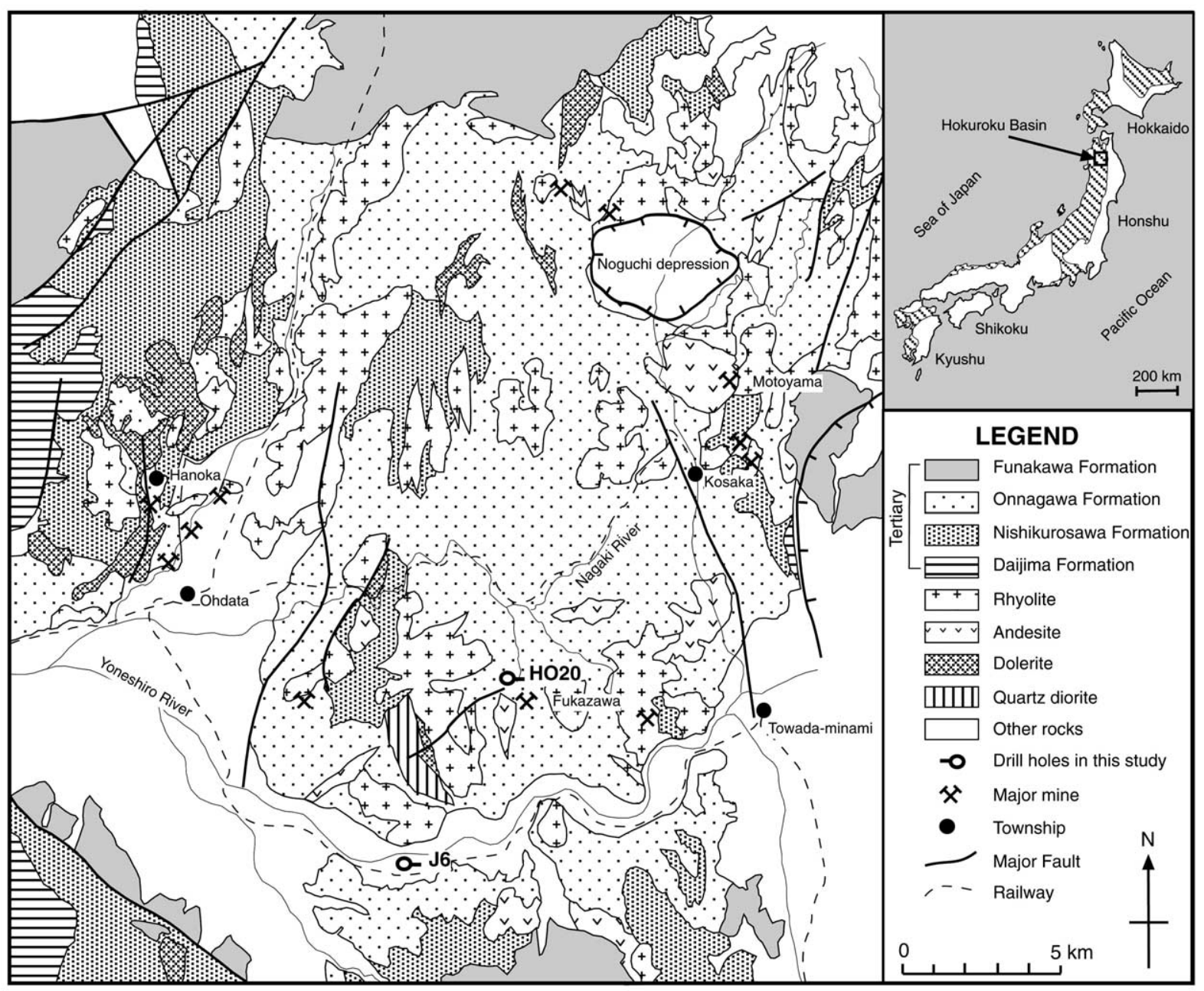

Fig. 6. Geology of the Hokuroku Basin, Japan, showing the distribution of the major lithostratigraphic units including the Nishikurosawa and Onnagawa Formations. Examples of pumiceous peperite were recognised in diamond drill holes HO20 and J6 near the Fukazawa VHMS deposit. Geology of the Hokuroku Basin after Tanimura et al. (1983) and the distribution of the Green Tuff Belt in Japan (striped area on inset map) after Sato (1974).

\subsection{Interbedded lithic-pumice breccia and sandstone}

Lithic-pumice breccia beds are up to $40 \mathrm{~m}$ thick and normally graded with stratified siltstone tops and lithic-rich bases (500-620 m, Fig. 8). Lithicpumice sandstone beds are typically $10-20 \mathrm{~m}$ thick, normally graded and diffusely stratified (Fig. 8). In both facies, the components are tube pumice clasts $(75 \%, 0.2-1.5 \mathrm{~cm})$, glass shards $(10 \%, 0.2-0.3 \mathrm{~mm})$, non-vesicular rhyolite clasts $(7 \%, 0.2-2 \mathrm{~cm})$, feldspar crystal fragments $(5 \%$,
0.2-1.5 mm), green plagioclase-phyric fiamme $(5 \%,<2 \mathrm{~cm})$ and mudstone clasts $(<1 \%)$. All original glass is completely altered. The plagioclase-phyric $(5 \%, 1-1.5 \mathrm{~mm})$ pumice clasts are variably altered to saponite, cristobalite, analcime, sericite or chlorite. The vesicles are commonly filled with mordenite. Pumice clasts are blocky or wispy and are both compacted and uncompacted. Glass shards have been altered to analcime. The non-vesicular rhyolite clasts include aphyric perlitic rhyolite, and plagioclase-phyric $(3 \%, 1 \mathrm{~mm})$ spherulitic and flow-banded rhyolite. 
The non-vesicular clasts are sub-angular and blocky with arcuate surfaces. Plagioclase phenocrysts are partially replaced by montmorillonite and saponite, whereas the groundmass is cristobalite or a mosaic of fine quartz and feldspar. Perlitic fractures are filled with chlorite. The green feldspar-phyric fiamme contain $5 \%, 1.5-\mathrm{mm}$ plagioclase phenocrysts in a groundmass of fine chlorite, sericite and saponite. The long axes of the fiamme are aligned parallel to bedding. In some fiamme, tube vesicles are preserved where they have been filled with analcime or mordenite. Mudstone clasts are elongate and ragged.

At the base of the lithic-pumice breccia beds, pumice clasts average 1 to $1.5 \mathrm{~cm}$, lithic clasts are less than $2 \mathrm{~cm}$ and rare mudstone clasts are between 0.5 and $5 \mathrm{~cm}$ in length. The stratified siltstone tops contain sparse outsize $(1.5-3 \mathrm{~cm})$ pumice clasts and fiamme. Convolute laminations, flames and load structures are typical of the upper contacts. The diffusely stratified sandstone commonly has feldspar crystal-rich bases that grade up-hole into pumiceous siltstone and grey volcanic mudstone. Locally the mudstone is bioturbated.

\subsection{Interbedded mudstone and sandstone}

Interbedded brown to dark-grey mudstone and volcanic sandstone occur in intervals between 60 $\mathrm{cm}$ and $6 \mathrm{~m}$ thick (795-810 m, Fig. 8). Sandstone beds are less than $20 \mathrm{~cm}$ thick, massive and tabular. The mudstone is laminated and bioturbated.

\subsection{Rhyolite facies association}

The rhyolite facies association consists of three facies: coherent rhyolite, pumiceous rhyolite, and monomictic pumiceous rhyolite breccia. The rhyolite facies association has a total maximum thickness of $90 \mathrm{~m}$ and has been intruded by syn-volcanic basaltic sills (Fig. 8). A basaltic sill separates the top of the rhyolite facies association from the overlying interbedded lithic-pumice breccia and sandstone. At the base of the rhyolite, monomictic pumiceous rhyolite breccia grades into pumiceous rhyolite-mudstone breccia (806 m; Fig. 8).
The coherent rhyolite facies exists in $1-5-\mathrm{m}$ intervals and grades vertically into pumiceous rhyolite and jigsaw-fit and clast-rotated monomictic pumiceous rhyolite breccia (Fig. 8). The coherent rhyolite contains $3 \%$, 1-mm plagioclase phenocrysts in a massive or flow-banded, fine groundmass of quartz-feldspar or cristobalite. Flow bands are defined by either microspherulitic or formerly glassy perlitic bands. The overlapping arcuate perlitic fractures are filled with chlorite (Fig. 8C). Coherent rhyolite varies from non-vesicular to poorly vesicular rhyolite $(\sim 7$ modal $\%$ ). Vesicles are filled with montmorillonite or chlorite and quartz (Fig. 8C).

A pumiceous rind ( $\sim 70$ modal $\%$ vesicularity) occurs at the margins of the coherent rhyolite where it resembles tube pumice. Pumiceous and non-vesicular flow bands also occur in the upper $30 \mathrm{~m}$ of the rhyolite (Fig. 8). Tube vesicles in the pumiceous rhyolite are filled with either mordenite or montmorillonite. Round vesicles are preserved immediately adjacent to plagioclase phenocrysts (Fig. 8B). The originally glassy walls are variably altered to sericite and mordenite.

The monomictic pumiceous rhyolite breccia facies occurs in intervals up to $20 \mathrm{~m}$ thick and grades into coherent pumiceous rhyolite and pumiceous rhyolite-mudstone breccia facies (Fig. 8). It is poorly sorted, clast-supported and massive with clast sizes varying from $0.5 \mathrm{~mm}$ to tens of $\mathrm{cm}$. The plagioclase-phyric $(3 \%, 2 \mathrm{~mm})$ tube pumice clasts have been altered to sericite and mordenite. Round vesicles filled with mordenite are preserved adjacent to plagioclase phenocrysts in the pumice clasts. The clasts are angular with ragged ends and blocky to tabular shapes (Fig. 8A). Some clasts are compacted and altered to chlorite (Fig. 8D). The tube vesicles in adjacent clasts have random orientations (Fig. 8A) although locally groups of clasts show jigsaw-fit texture.

\subsection{Pumiceous rhyolite-mudstone breccia facies}

Three intervals of pumiceous rhyolite-mudstone breccia facies occur at the base of the rhyolite facies association (790 to $810 \mathrm{~m}$, Fig. 8). A 4$\mathrm{m}$-thick interval of pumiceous rhyolite-mudstone 


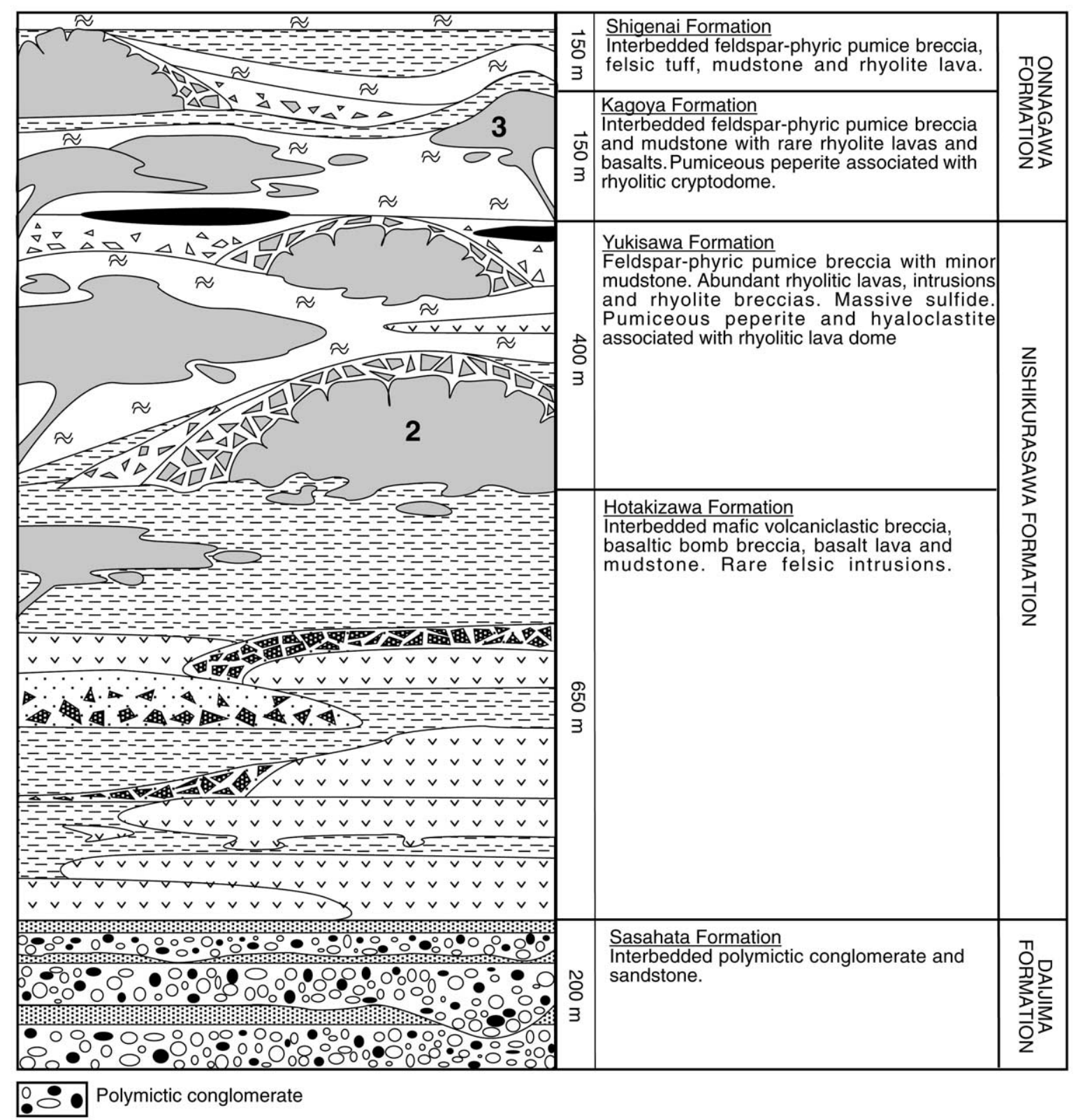

Fig. 7. Schematic diagram of the simplified stratigraphy and facies architecture of rocks in the Fukazawa area in the central Hokuroku Basin. Refer to Fig. 2 for legend. 2, pumiceous peperite at the base of a pumiceous rhyolitic lava dome that flowed over unconsolidated interbedded mudstone and sandstone. 3, pumiceous peperite at the margins of a pumiceous rhyolitic cryptodome complex that intruded into unconsolidated interbedded pumice-rich facies. Stratigraphy of the central Hokuroku Basin is modified after Tanimura et al. (1983), Nakajima (1988), Horikoshi (1969) and Gifkins (unpublished data).

breccia grades vertically up into monomictic pumiceous rhyolite breccia facies and down into interbedded mudstone and sandstone. Intervals of pumiceous rhyolite-mudstone breccia a few $\mathrm{cm}$ thick also occur below and above a 2-m-thick interval of pumiceous rhyolite below the main contact.

The pumiceous rhyolite-mudstone breccia fa- 

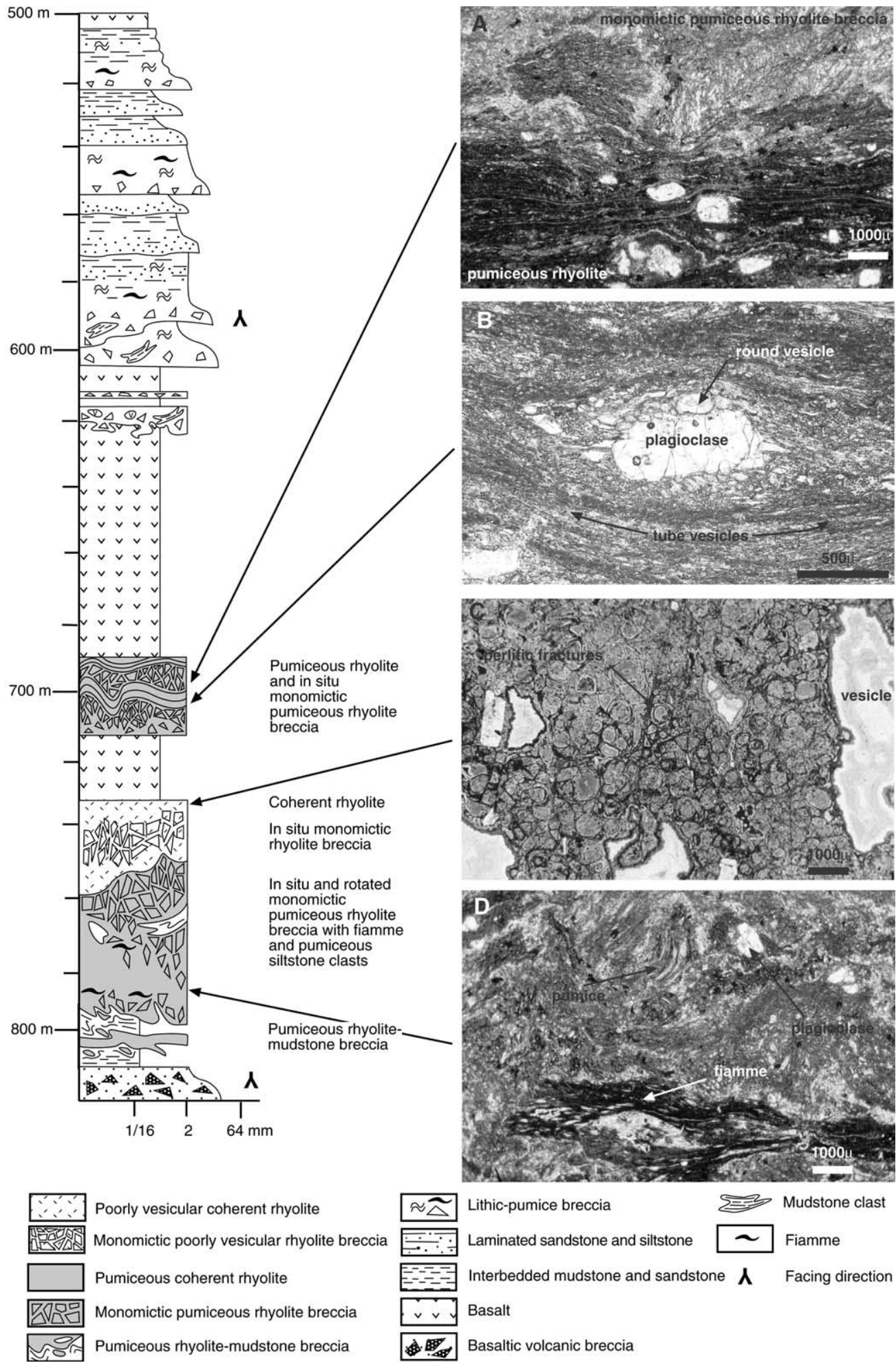

Lithic-pumice breccia

Mudstone clast Laminated sandstone and siltstone $\sim$ Fiamme Interbedded mudstone and sandstone $\boldsymbol{\Lambda} \quad$ Facing direction Basalt

Basaltic volcanic breccia 
cies is poorly sorted and massive. It is dominated by close-packed pumice clasts in a fine-grained silicified matrix. The matrix is commonly limited to thin seams or stringers of mudstone between pumice clasts although at one contact pumiceous rhyolite clasts are isolated in massive mudstone. The pumice clasts vary in size from $1 \mathrm{~mm}$ to several tens of $\mathrm{cm}$ and have thin selvedges of pale green silicified mudstone. The pumice clasts are blocky, variably compacted and plagioclase-phyric $(3 \%, 1 \mathrm{~mm})$.

\subsection{Interpretation}

Coherent rhyolite, pumiceous rhyolite and monomictic pumiceous rhyolite breccia are closely spatially associated, and have gradational contacts and identical phenocryst populations and mineralogy. The pumice clasts in the monomictic pumiceous rhyolite breccia are texturally similar to the pumiceous rhyolite. This suggests that these three facies are genetically related and that the pumice clasts in the monomictic pumiceous rhyolite breccia are derived from disintegration of the pumiceous rhyolite. In particular, clast shapes and arrangement in the monomictic pumiceous rhyolite breccia are typical of clast-rotated and resedimented hyaloclastite (cf. Pichler, 1965).

The gradational contacts between monomictic pumiceous rhyolite breccia, pumiceous rhyolitemudstone breccia and mudstone are consistent with the interpretation that the pumiceous rhyolite intruded and mingled with mud to produce pumiceous peperite. Silicified mudstone between pumice clasts and in fractures in the rhyolite indicate that the mud was unconsolidated and remobilised during emplacement of the rhyolite. As the rhyolite lava flowed over or intruded the wet unconsolidated mud, mud was injected into fractures in the rhyolite and subsequently baked by contact metamorphism (cf. Busby-Spera and White, 1987). The thickness (90 m) of the rhyolite facies association and the abundance of clast-rotated textures in the monomictic pumiceous rhyolite breccia are consistent with a rhyolitic lava dome or cryptodome (cf. Scutter et al., 1998). The simple gradation from coherent non-vesicular rhyolite through pumiceous rhyolite to jigsaw-fittextured and clast-rotated monomictic pumiceous rhyolite breccia suggests that growth of the lava dome involved endogenous expansion from the interior during a single eruptive phase.

\section{Pumiceous peperite and hyaloclastite associated with a cryptodome in the Green Tuff Belt}

\subsection{Geological setting}

Pumiceous hyaloclastite and peperite in drill hole $\mathrm{HO} 20$ are associated with rhyolitic intrusions in the Fukazawa mine hangingwall, in the central Hokuroku Basin (Figs. 7 and 9). The hangingwall is the Onnagawa Formation and consists of pumice breccia, sandstone and siltstone (pumice-rich facies association), and bioturbated mudstone interbedded with rhyolitic lavas and intrusions. The rhyolites are interpreted to be contemporaneous with the emplacement of the pumice breccias (Nakajima, 1988). The lower pumice breccia is extensive and has been used to correlate stratigraphy across the Hokuroku District (Urabe, 1987).

\subsection{Pumice-rich facies association}

Interbedded pumice breccia, sandstone and siltstone facies comprise normally graded, moderately well sorted beds of $20 \mathrm{~m}$ average thickness.

Fig. 8. Graphic $\log$ of diamond drill hole J6 showing the distribution of interbedded lithic-pumice breccia and sandstone, interbedded mudstone and sandstone, pumiceous rhyolite, monomictic pumiceous rhyolite breccia and pumiceous rhyolite-mudstone breccia facies. (A) Photomicrograph ( $\mathrm{ppl}$ ) of the contact between pumiceous rhyolite and monomictic pumiceous rhyolite breccia. Tube vesicles in the pumice clasts are commonly aligned parallel to tube vesicles in the pumiceous rhyolite. (B) Photomicrograph (ppl) of pumiceous rhyolite. Round vesicles are preserved adjacent to the plagioclase phenocryst. Vesicles are mordenite-filled and originally glassy walls are replaced by sericite. (C) Photomicrograph (ppl) of poorly vesicular coherent rhyolite. The groundmass contains abundant arcuate, chlorite-filled perlitic fractures and sparse chlorite-montmorillonite-filled vesicles. (D) Photomicrograph (ppl) of monomictic pumiceous rhyolite breccia with uncompacted and compacted (fiamme) tube pumice clasts. 

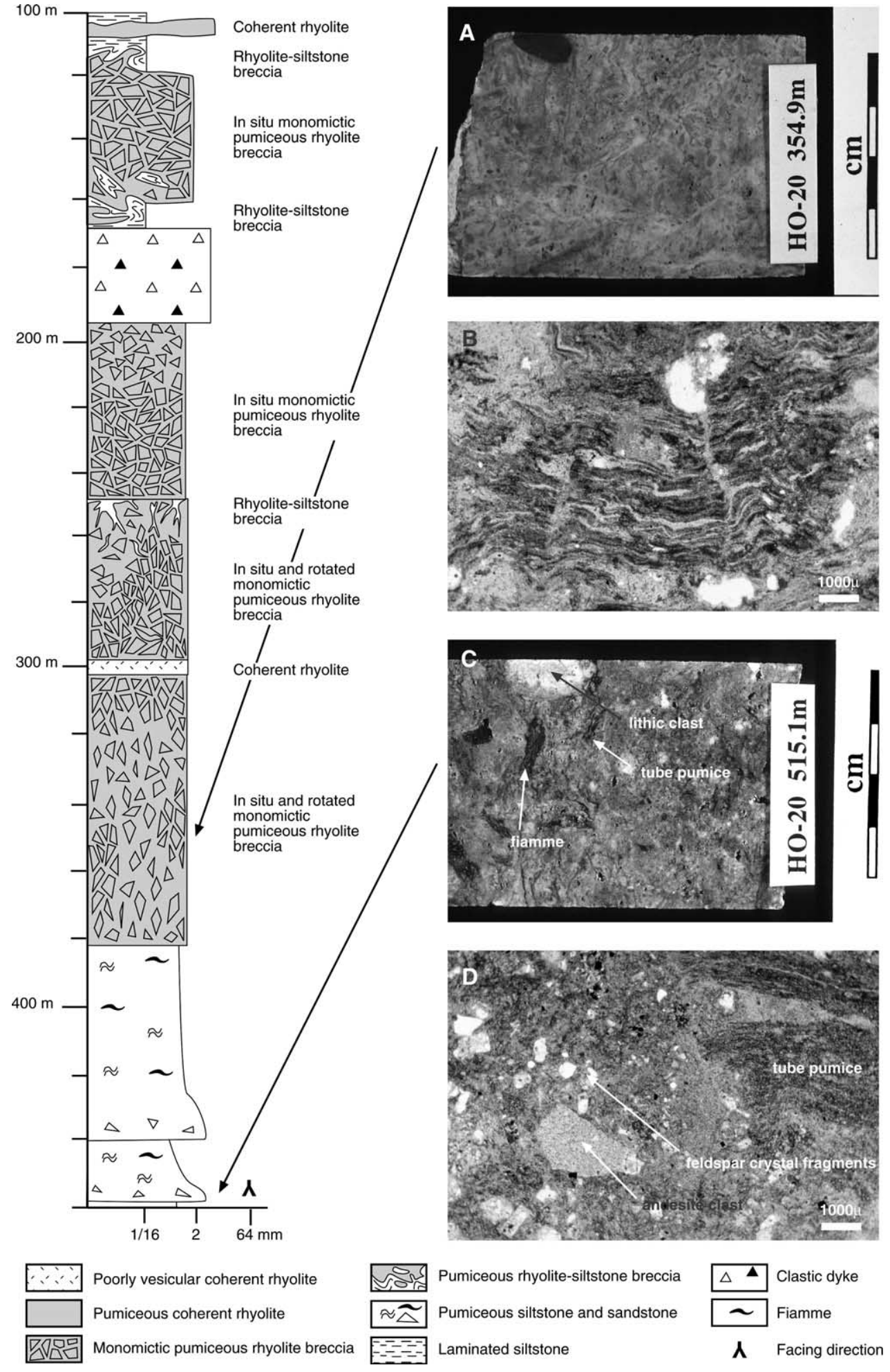

Pumiceous rhyolite-siltstone breccia

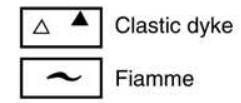

ZVD司 Monomictic pumiceous rhyolite breccia

Laminated siltstone

A Facing direction 
The pumice breccia beds have lithic-rich bases and grade upwards to sandstone or siltstone.

The components of this facies are plagioclasephyric tube pumice clasts $(70 \%, 6 \mathrm{~mm})$, shards $(20 \%, 0.5 \mathrm{~mm})$, feldspar crystal fragments $(7 \%$, $0.2-2 \mathrm{~mm})$, fiamme $(5 \%, 0.5 \mathrm{~mm}-3 \mathrm{~cm})$ and non-vesicular volcanic clasts $(3 \%, 0.3-4 \mathrm{~cm})$ (Fig. 9C,D). Pumice clasts have 5\%,1-mm plagioclase phenocrysts, irregular shapes and ragged terminations perpendicular to the tube vesicles. Most are oriented roughly parallel to bedding, although some are oriented at steep angles. The originally glassy vesicle walls are altered to smectite that is variably replaced by sericite, and the vesicles are filled with mordenite. Plagioclase is partially to completely replaced by sericite or saponite. The green plagioclase-phyric fiamme are interpreted to be altered and compacted pumice clasts. Subrounded, non-vesicular volcanic clasts include plagioclase-phyric flow-banded, perlitic or densely microspherulitic rhyolite $(2-5 \%$ total volume $)$ and fine, massive, aphyric andesite $(<1 \%$ total volume).

\subsection{Rhyolite facies association}

The rhyolite facies association consists of coherent rhyolite and monomictic pumiceous rhyolite breccia facies. The rhyolite facies association has a total thickness of $220 \mathrm{~m}$ and comprises thin intervals $(<10 \mathrm{~m})$ of coherent rhyolite surrounded by jigsaw-fit and clast-rotated monomictic pumiceous rhyolite breccia (Fig. 9). Some intervals of monomictic pumiceous rhyolite breccia have gradational upper or lower contacts with rhyolite-siltstone breccia (Fig. 9).

The coherent rhyolite facies is massive, plagioclase-phyric $(5 \%, 1 \mathrm{~mm})$ and vesicular. Vesicles are filled with zeolites, and the originally glassy groundmass is variably replaced by smectite, sericite, feldspar and quartz. Plagioclase phenocrysts are altered to sericite and coated by montmorillonite. The coherent rhyolite contains sparse clasts of pumiceous and shard-rich siltstone and andesite. Siltstone clasts occur mainly in the margins of the rhyolite $(\sim 137 \mathrm{~m}$, Fig. 9$)$ and are elongate (up to $20 \mathrm{~cm}$ ).

The monomictic pumiceous rhyolite breccia facies occurs in massive, poorly sorted, and clastsupported intervals between 5 and $20 \mathrm{~m}$ thick (Fig. 9). Monomictic pumiceous rhyolite breccia comprises plagioclase-phyric $(5 \%, 1 \mathrm{~mm})$ tube pumice clasts in a fine recrystallised matrix of sericite, quartz and feldspar (Fig. 9B). Pumice clasts average $1 \mathrm{~cm}$ in length $(1 \mathrm{~mm}$ to $10 \mathrm{~cm})$, and are angular, blocky and uncompacted. Tube vesicles are filled with zeolites and/or feldspar and the originally glassy vesicle walls are replaced by fine feldspar-quartz and sericite-chlorite assemblages resulting in green- and white-striped clasts (Fig. 9A). The tube vesicles and long axes of most pumice clasts are oriented perpendicular to bedding in the interbedded pumice-rich facies. Sparse andesite clasts are also present; these are subrounded and up to $1.5 \mathrm{~cm}$ in diameter.

\subsection{Rhyolite-siltstone breccia facies}

Rhyolite-siltstone breccia consists of a texturally complex mixture of pumiceous rhyolite clasts and siltstone. Intervals of rhyolite-siltstone breccia are $1-10 \mathrm{~m}$ thick and grade vertically into monomictic pumiceous rhyolite breccia or siltstone (Fig. 9). This facies is massive, poorly sorted and varies from clast-supported to matrix-supported.

Plagioclase-phyric $(5 \%,<1 \mathrm{~mm})$ rhyolite clasts are uncompacted pumiceous, blocky and are $2 \mathrm{~mm}$ to $10 \mathrm{~cm}$ in length. The siltstone is pale grey, massive and silicified and occurs as ragged clasts (less than $20 \mathrm{~cm}$ in length) and as a matrix enclosing isolated pumiceous rhyolite clasts. There is a

Fig. 9. Graphic log of diamond drill hole HO20 showing the distribution of interbedded pumice-rich facies, coherent rhyolite, monomictic pumiceous rhyolite breccia facies and rhyolite-siltstone breccia facies. (A) Monomictic pumiceous rhyolite breccia composed of green- and white-striped pumice clasts that are predominantly orientated parallel to the base of the photograph. (B) Photomicrograph (ppl) of a sericite-, feldspar- and quartz-altered tube pumice clast in monomictic pumiceous rhyolite breccia. (C) Lithic-rich base of a pumice breccia bed. (D) Photomicrograph (ppl) of tube pumice clast and andesite clast in the lithic-rich base of a pumice breccia bed. 
gradation from close-packed pumiceous rhyolite clasts separated by fractures filled with silicified siltstone to pumiceous rhyolite clasts dispersed in siltstone.

\subsection{Interpretation}

The presence of jigsaw-fit texture in the monomictic pumiceous rhyolite breccia suggests that it is derived from in situ brittle fragmentation of coherent rhyolite. The steep orientation of tube vesicles in pumice clasts in the monomictic pumiceous rhyolite breccia could reflect steeply dipping flow bands in the rhyolite. The blocky, angular pumice clasts, abundance of domains with jigsaw-fit texture and the lack of matrix suggest that the monomictic pumiceous rhyolite is intrusive pumiceous hyaloclastite (cf. Pichler, 1965; Hanson, 1991).

The gradation from monomictic pumiceous rhyolite breccia to rhyolite-siltstone breccia, the silicified and homogeneous character of the siltstone within the rhyolite-siltstone breccia facies, and complex clast-matrix relationships, are all consistent with the interpretation of rhyolite-siltstone breccia facies as pumiceous peperite. The presence of pumiceous peperite, and the irregular and complex geometry of the upper contact of the rhyolite facies association (coherent rhyolite and pumiceous hyaloclastite) are consistent with the intrusion of pumiceous rhyolite into unconsolidated host sediment facies. The host facies is the pumice-rich facies association which is composed of interbedded bioturbated mudstone and massflow-emplaced pumice breccia and sandstone.

The rhyolite facies associations are not laterally extensive $(<500 \mathrm{~m})$ and they are composed of lobes of coherent rhyolite interfingering with thick $(<20 \mathrm{~m})$ monomictic pumiceous rhyolite breccia. This is typical of rhyolitic cryptodomes (cf. Allen, 1992).

\section{Comparison of pumiceous peperite with other submarine pumice-rich facies}

Pumiceous peperite can resemble other pumicerich facies that are common in submarine volcanic successions. Pumiceous debris in the submarine environment can be produced as a result of intrabasinal and extrabasinal explosive eruptions and autoclastic fragmentation (autobrecciation, quenching) of pumiceous lavas or intrusions. The positive identification of peperite requires evidence that the host sediment was unconsolidated at the time of mingling and that the igneous component was molten.

The examples discussed in this paper are interpreted as peperite because:

(1) The sediment component in the peperite, whether that be pumice breccia, siltstone, or mudstone, is massive and unstratified, whereas elsewhere the host sediment is graded, stratified or laminated. Local destruction of original depositional structures requires that the host sediment was unconsolidated or only poorly consolidated, allowing easy disruption of grain contacts.

(2) Sediment immediately adjacent to pumiceous rhyolite clasts within the peperite, and sediment close to contacts with the coherent rhyolite are silicified compared to sediment away from the rhyolite. This local silicification is interpreted to reflect baking or induration of sediment in contact with hot rhyolite.

(3) There are gradational contacts between coherent rhyolite, monomictic pumiceous rhyolite breccia, pumiceous rhyolite-sediment peperite (polymictic pumice breccia, pumiceous rhyolitesiltstone breccia and pumiceous rhyolite-mudstone breccia) and host sediment (pumice breccia, siltstone and mudstone, respectively).

(4) Dispersal of pumiceous rhyolite clasts in the host sediment is limited to distances of less than $5 \mathrm{~m}$ (usually less than $50 \mathrm{~cm}$ ) from contacts with monomictic pumiceous rhyolite breccia and/or coherent rhyolite.

In submarine settings, pumice-sediment mixtures can be generated by mechanisms other than the mingling of hot pumiceous rhyolite with wet unconsolidated sediment (Fig. 10). Pumiceous mass flows can incorporate sediment from the substrate as intraclasts and/or matrix (Fig. 10B) (Kokelaar et al., 1985; Dimroth and Yamagishi, 1987; McPhie and Allen, 1992). Unconsolidated clasts of mud or silt may disintegrate during transport contributing to fine-grained matrix (Sie- 

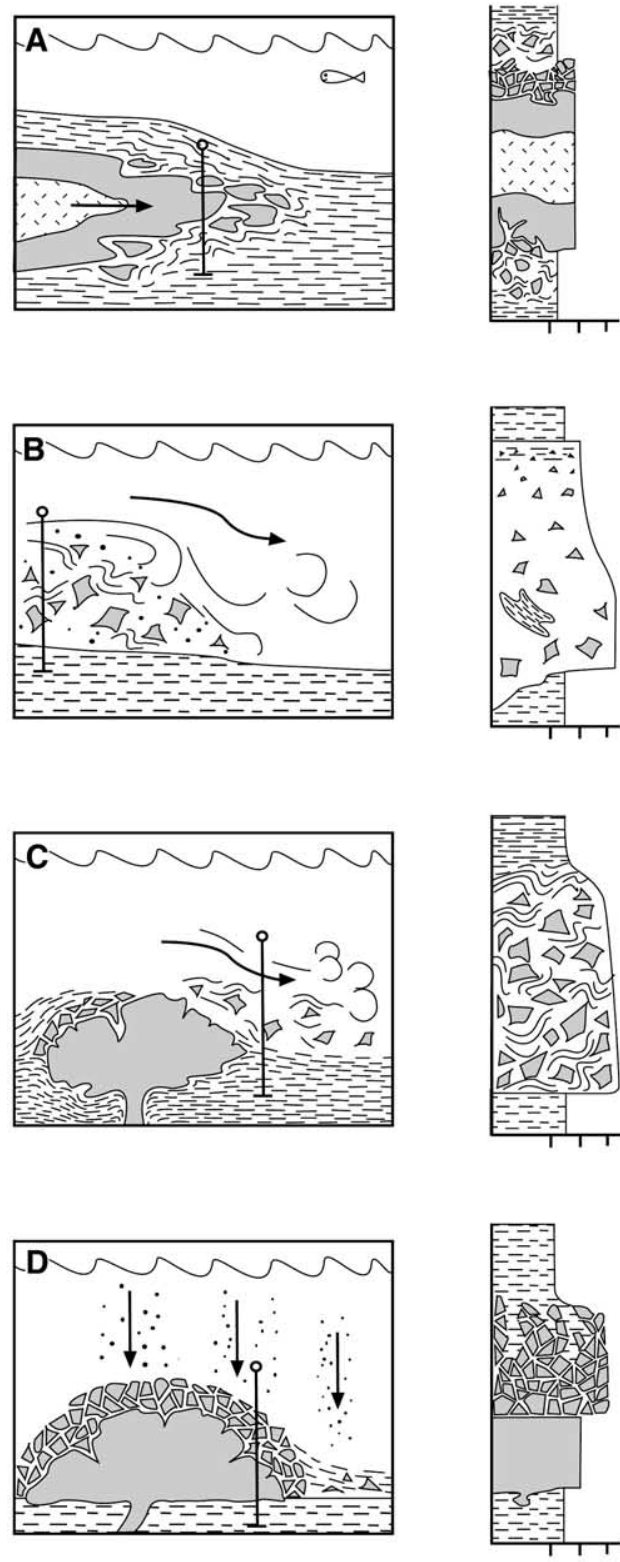

bert, 1984; McPhie et al., 1993). Laminae in sediment intraclasts and in underlying sediment may be locally deformed or destroyed. Deposits from these mass flows typically form laterally continuous beds that may extend for $100 \mathrm{~s}$ of $\mathrm{m}$ or $\mathrm{km}$ (Fiske, 1969; Fisher and Schmincke, 1984; Allen and Cas, 1990). Although superficially similar, pumice-sediment peperite generally has limited extent (10s to $100 \mathrm{~s}$ of $\mathrm{m}$ ) and volume, can be markedly disconformable, is spatially associated with the margins of intrusions, and the sediment component shows evidence of baking.

Pumice clasts and sediment may also be mixed as a result of slumping and resedimentation of sediment and dome margin debris during growth of a partly extrusive cryptodome (Fig. 10C) (cf. Horikoshi, 1969; Kokelaar et al., 1985; Cas et al., 1990). This pumice-sediment mixture can be distinguished from pumiceous peperite mainly by its occurrence in diffusely stratified or weakly graded lenticular beds. The distinction may however be far from clear as both facies can include groups of pumice clasts that show jigsaw-fit texture and sediment that is locally indurated adjacent to pumice clasts derived from the dome carapace.

Pumiceous peperite could also be confused with pumiceous hyaloclastite or autobreccia that has a fine sediment matrix due to infiltration of sediment into open spaces between clasts (Fig. 10D). Such infilling sediment is typically fine-grained (granules and finer) and planar-stratified with bedding orientations consistent among all the sediment domains (Rawlings et al., 1999). In contrast to the locally indurated host sediment domains in pumiceous peperite, infilling sediment is not affected by contact metamorphism.
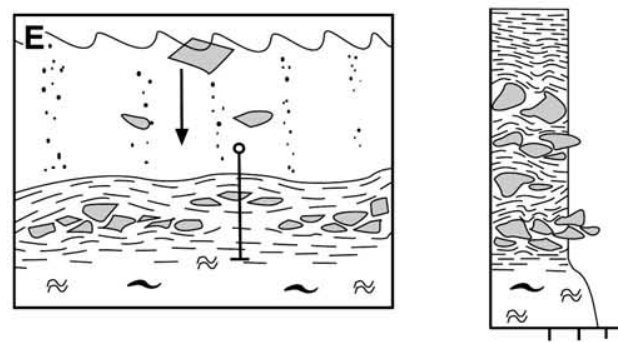

Fig. 10. Cartoons of the different mechanisms that may generate pumice-sediment mixtures in the submarine environment and schematic logs through the resulting deposits at the position indicated, showing the textural facies characteristics. Refer to Fig. 3 for legend. (A) The intrusion of pumiceous rhyolite into wet unconsolidated sediment. (B) Pumiceous mass flow incorporating intrabasinal sediment. (C) Infiltration of sediment into pumiceous hyaloclastite or autobreccia. (D) Resedimentation of dome margin debris and sediment cover above and emerging cryptodome. (E) Outsized water-logged pumice clasts in fine-grained suspension sediment. 
Pumiceous clasts that are initially buoyant eventually become water-logged and sink, being deposited at the same time as much finer sediment settling from suspension (Fig. 10E) (Reynolds et al., 1980; Fiske et al., 1998). The result is a laterally extensive deposit composed of outsized pumice clasts in laminated siltstone and mudstone. Compaction causes a dramatic change in the shapes of pumice clasts and contortion of sedimentary laminae, producing a facies that can resemble pumiceous peperite (Hunns and McPhie, 1999). However, water-settled pumice-sediment mixtures typically occur in laterally continuous beds. Although contorted, stratification in the sediment domains is generally well preserved and may drape large pumice blocks, and the sediment shows no evidence of induration. Such mixtures typically occur in the fine-grained tops of pumiceous mass-flow units or in overlying suspension sediment intervals, and may be far removed from any coherent pumiceous rhyolite in the succession.

\section{The formation of pumiceous peperite}

The examples of pumiceous peperite described here are characterised by a transition from in situ pumiceous hyaloclastite to pumiceous peperite, the presence of pumice clasts with chilled margins and curviplanar surfaces, and abundant jigsaw-fit textures. This implies that quench fragmentation and autobrecciation were the dominant mechanism of clast formation (cf. Pichler, 1965; De Rosen-Spence et al., 1980; Hanson and Wilson, 1993).

In the two examples of pumiceous peperite from the Hokuroku Basin, jigsaw-fit texture predominates and the dispersal of pumice clasts was very limited. Dynamic stressing of more brittle parts of the pumiceous rhyolite, propagation of thermal contraction cracks and the injection of mobile sediment along fractures can adequately account for the textural and facies characteristics observed. Pumice clasts in the Koonya pumiceous peperite have chilled margins, curviplanar surfaces and local jigsaw-fit texture, consistent with quench fragmentation, but the pumice clasts are more dispersed in the host stratified pumice breccia. In this case, the mingling of pumice clasts with the stratified pumice breccia may have been facilitated by steam explosions (Kokelaar, 1986; Wohletz, 1983; Branney and Suthren, 1988) or the convective circulation of superheated pore water and sediment (Kokelaar, 1982).

The pumiceous nature of the rhyolite in these examples implies that volatile exsolution was not inhibited by confining pressure nor arrested by cooling prior to fragmentation. Low confining pressures, less than $10 \mathrm{MPa}$, require that the sediment cover above the pumiceous rhyolite was thin and that the water depth was probably less than $200 \mathrm{~m}$ (McBirney, 1963; Hunns and McPhie, 1999). Delayed quenching of the rhyolite to allow vesiculation suggests that the rhyolite was, at least initially, insulated. This may have been achieved by the development of a vapour film at the contact between the molten rhyolite and unconsolidated host sediment. This is consistent with the possibility of steam explosions in the example from Koonya.

\section{Conclusions}

Distinctive mixtures of pumiceous rhyolite and clastic sediment occur within the submarine volcanic successions of the Mount Read Volcanics, Tasmania, and the Green Tuff Belt, Japan. These mixtures are interpreted to be pumiceous peperite, based on evidence that the pumiceous rhyolite was hot, that the sediment was wet and unconsolidated at the time of mingling, and that mingling occurred in situ at the margins of intrusions or lavas.

Pumiceous peperite resembles other pumicesediment mixtures that are common in submarine felsic volcanic successions. Diagnostic features of pumiceous peperite are: (1) gradational relationships among the host sediment, pumiceous peperite, in situ monomictic pumiceous rhyolite breccia and coherent pumiceous rhyolite; (2) local destruction of depositional structures in the sediment; (3) local silicification or induration of sediment adjacent to pumiceous rhyolite clasts; and (4) the massive, laterally discontinuous character 
of this facies. The recognition of pumiceous peperite is important for interpreting the facies architecture and stratigraphic relationships in the volcanic succession and provides limits on the age relationships and timing of the pumiceous intrusions.

Pumiceous peperite resulted from the interaction of highly vesicular rhyolitic magma intruding or flowing over wet unconsolidated sediment. Fragmentation of the pumiceous rhyolite was predominantly a result of quenching and dynamic stressing of the cooler, more viscous parts of the moving rhyolite. Sediment was injected into fractures propagating into the hot pumiceous rhyolite, resulting in local destruction of depositional structures in the host sediment and local induration.

The formation of pumiceous peperite requires the expansion of magmatic volatiles prior to cooling and fragmentation. Conditions that favour this are low confining pressure and insulation of the rhyolite from quenching during volatile exsolution.

\section{Acknowledgements}

The research in this paper was completed as part of a larger research project funded by a Mineral Resources Tasmania scholarship and sponsored by the Australian Research Council. Logistical support in western Tasmania was provided by Pasminco Exploration. In Japan, logistical support was provided by Akita University, Akita Prefecture Resources and the Metal Mining Agency of Japan. Professor Ohguchi and Dr Okamoto are gratefully acknowledged for their invaluable assistance arranging access to drill holes and drill data in the Hokuroku Basin. We also thank JVGR referees Richard Fiske and Patricia Corcoran for their enthusiastic reviews of the manuscript.

\section{References}

Allen, R.L., 1994a. Volcanic facies analysis indicates large pyroclastic eruptions, sill complexes, syn-volcanic grabens and subtle thrusts in the Cambrian 'Central Volcanic Complex' volcanic centre, western Tasmania. In: Cooke, D.R., Kitto,
P.A. (Eds.), Contentious Issues in Tasmanian Geology. Geol. Soc. Aust. Abstr. 39, 41-43.

Allen, R.L., 1994b. Syn-volcanic, sub-seafloor replacement model for Rosebery and other massive sulfide ores. In: Cooke, D.R., Kitto, P.A. (Eds.), Contentious Issues in Tasmanian Geology. Geol. Soc. Aust. Abstr. 39, 107-108.

Allen, R.L., 1992. Reconstruction of the tectonic, volcanic, and sedimentary setting of strongly deformed $\mathrm{Zn}-\mathrm{Cu}$ massive sulfide deposit at Benambra, Victoria. Econ. Geol. 87, 825-854.

Allen, R.L., Cas, R.A.F., 1990. The Rosebery controversy: Distinguishing prospective submarine ignimbrite-like units from true subaerial ignimbrites in the Rosebery-Hercules $\mathrm{Zn} \mathrm{Cu} \mathrm{Pb}$ massive sulfide district, Tasmania. 10th Aust. Geol. Convention, Geol. Soc. Aust. Abstr. 25, 31-32.

Allen, R.L., Hunns, S.R., 1990. Geology of the Hercules and South Hercules Ore Bodies. Excursion Guide E1. The Mount Read Volcanics and related ore deposits. 10th Aust. Geol. Convention, Geol. Soc. Aust. Abstr. 25, 1527.

Berry, R.F., 1989. The history of movement of the Henty fault zone, western Tasmania: An analysis of fault striations. Aust. J. Earth Sci. 36, 189-206.

Braithwaite, R.L., 1974. The geology and origin of the Rosebery ore deposit, Tasmania. Econ. Geol. 69, 1086-1101.

Branney, M.J., Suthren, R.J., 1988. High-level peperitic sills in the English Lake District: distinction from block lavas and implications for Borrowdale Volcanic Group stratigraphy. Geol. J. 23, 171-187.

Busby-Spera, C.J., White, J.D.L., 1987. Variation in peperite textures associated with differing host-sediment properties. Bull. Volcanol. 49, 765-775.

Cas, R.A.F., Allen, R.L., Bull, S.W., Clifford, B.A., Wright, J.V., 1990. Subaqueous, rhyolitic dome-top tuff cones: a model based on the Devonian Bunga Beds, southeastern Australia and a modern analogue. Bull. Volcanol. 52, 159174.

Corbett, K.D., 1992. Stratigraphic-volcanic setting of massive sulfide deposits in the Cambrian Mount Read Volcanics, Tasmania. Econ. Geol. 87, 564-586.

Corbett, K.D., Lees, T.C., 1987. Stratigraphic and structural relationships and evidence for Cambrian deformation at the western margin of the Mt Read Volcanics, Tasmania, Australia. Aust. J. Earth Sci. 34, 45-67.

Corbett, K.D., Solomon, M., 1989. Cambrian Mt Read Volcanics and associated mineral deposits. In: Burrett, C.F., Martin, E.L. (Eds.), 1989, Geology and Mineral Resources of Tasmania. Spec. Publ. Geol. Soc. Aust. 15, 84-153.

Crawford, A.J., Berry, R.F., 1992. Tectonic implications of Late Proterozoic-Early Palaeozoic igneous rock associations in western Tasmania. Tectonophysics 214, 37-56.

Crawford, A.J., Corbett, K.D., Everard, J.L., 1992. Geochemistry of the Cambrian volcanic-hosted massive sulfide-rich Mount Read Volcanics, Tasmania, and some tectonic implications. Econ. Geol. 87, 597-619.

De Rosen-Spence, A.F., Provost, G., Dimroth, E., Gochnauer, K., Owen, V., 1980. Archaean subaqueous felsic flows, 
Rouyn-Noranda, Quebec, Canada and their Quaternary equivalents. Precambr. Res. 12, 43-77.

Dimroth, E., Yamagishi, H., 1987. Criteria for the recognition of ancient subaqueous pyroclastic rocks. Rep. Geol. Surv. Hokkaido 58, 55-88.

Dudas, F.O., Campbell, I.H., Gorton, M.P., 1983. Geochemistry of igneous rocks in the Hokuroku District, northern Japan. In: Ohmoto, H., Skinner, B.J. (Eds.), The Kuroko and Related Volcanogenic Massive Sulfide Deposits. Econ. Geol. Monogr. 5, 115-133.

Fink, J., 1983. Surface folding and viscosity of rhyolite flows. Geology 8, 250-254.

Fink, J.H., Manley, C.R., 1987. Origin of pumiceous and glassy textures in rhyolitic flows and domes. In: Fink, J.H. (Ed.), The Emplacement of Silicic Domes and Lava Flows. Geol. Soc. Am. Spec. Pap. 212, 77-88.

Fisher, R.V., Schmincke, H.-U., 1984. Pyroclastic Rocks. Springer, New York, 472 pp.

Fiske, R.S., 1969. Recognition and significance of pumice in marine pyroclastic rocks. Geol. Soc. Am. Bull. 80, 1-8.

Fiske, R.S., Cashman, K.V., Shibata, A., Watanabe, K., 1998. Tephra dispersal from Myojinsho, Japan, during its shallow submarine eruption of 1952-1953. Bull. Volcanol. 59, 262275.

Gifkins, C.C., Allen, R.A., McPhie, J., 1998. Ancient examples of pumiceous peperite and hyaloclastite. IAVCEI, Cape Town, July 1998, Abstr. 22.

Gifkins, C.C., Allen, R.A., McPhie, J., 1996. Fiamme associated with silicic lavas and intrusions. EOS Trans. AGU 77, W125.

Green, G.R., Solomon, M., Walshe, J.L., 1981. The formation of the volcanic-hosted massive sulfide deposit at Rosebery, Tasmania. Econ. Geol. 76, 304-338.

Guber, A.L., Merill, S., III, 1983. Paleobathymetric significance of Foraminifera from the Hokuroku District. In: Ohmoto, H., Skinner, B.J. (Eds.), The Kuroko and Related Volcanogenic Massive Sulfide Deposits. Econ. Geol. Monogr. 5, 55-70.

Hanson, R.E., 1991. Quenching and hydroclastic distribution of andesitic to rhyolitic intrusions in a submarine island-arc sequence, northern Sierra Nevada, California. Geol. Soc. Am. Bull. 103, 804-816.

Hanson, R.E., Wilson, T.J., 1993. Large-scale rhyolitic peperites (Jurassic, southern Chile). J. Volcanol. Geotherm. Res. 54, 247-264.

Horikoshi, E., 1969. Volcanic activity related to the formation of the Kuroko-type deposits in the Kosaka District, Japan. Miner. Depos. 4, 321-345.

Hunns, S.R., McPhie, J., 1999. Pumiceous peperite in a submarine volcanic succession at Mount Chalmers, Queensland, Australia. J. Volcanol. Geotherm. Res. 88, 239-254.

Kano, K., Yamamoto, T., Ono, K., 1996. Subaqueous eruption and emplacement of the Shinjima Pumice, Shinjima (Moeshima) Island, Kagoshima Bay, SW Japan. J. Volcanol. Geotherm. Res. 71, 187-206.

Kano, K., Takeuchi, K., Yamamoto, T., Hoshizumi, H., 1991. Subaqueous rhyolite block lavas in the Miocene Ushikiri
Formation, Shimane Peninsula, SW Japan. J. Volcanol. Geotherm. Res. 46, 241-253.

Kokelaar, P., 1986. Magma-water interactions in subaqueous and emergent basaltic volcanism. Bull. Volcanol. 48, 275289.

Kokelaar, B.P., 1982. Fluidisation of wet sediments during emplacement and cooling of various igneous bodies. J. Geol. Soc. London 139, 21-33.

Kokelaar, B.P., Bevins, R.E., Roach, R.A., 1985. Submarine silicic volcanism and associated sedimentary and tectonic processes, Ramsey Island, SW Wales. J. Geol. Soc. London 142, 591-613.

Kurokawa, A., 1991. Formation of felsic pumiceous hyaloclastites: a case study from Tadami district, Fukushima Prefecture, Japan (in Japanese with English abstract). Ganko J. Mineral. Petrol. Econ. Geol. 88, 439-458.

Lees, T.C., 1987. Geology and Mineralisation of the Rosebery-Hercules Area, Tasmania. Unpublished Masters Thesis, University of Tasmania.

McBirney, A.R., 1963. Factors governing the nature of submarine volcanism. Bull. Volcanol. 26, 455-469.

McPhie, J., Doyle, M., Allen, R.L., 1993. Volcanic Textures: a Guide to the Interpretation of Textures in Volcanic Rocks. Centre for Ore Deposit and Exploration Studies, University of Tasmania, Hobart, 198 pp.

McPhie, J., Allen, R.L., 1992. Facies architecture of mineralised submarine volcanic sequences: Cambrian Mount Read Volcanics, western Tasmania. Econ. Geol. 87, 587-596.

Nakajima, T., 1988. Geology of the Hokuroku Basin. In: Ishihara-Shunso (Ed.), Kuroko Deposits and Geothermal Fields in Northern Honshu. Geol. Soc. Min. Geol. Jpn. Guideb. 3, 5-15.

Ohmoto, H., Takahashi, T., 1983. Part III. Submarine calderas and Kuroko genesis. In: Ohmoto, H., Skinner, B.J. (Eds.), The Kuroko and Related Volcanogenic Massive Sulfide Deposits. Econ. Geol. Monogr. 5, 39-54.

Pichler, H., 1965. Acid hyaloclastites. Bull. Volcanol. 28, 293 310.

Rawlings, D.J., Watkeys, M.J., Sweeney, R.J., 1999. Peperitic upper margin of an invasive flow, Karoo flood basalt province, northern Lebombo. S. Afr. J. Geol. 102, 377-383.

Reynolds, M.A., Best, J.G., Johnson, R.W., 1980. 1953-57 eruption of Tuluman volcano: rhyolitic volcanic activity in the northern Bismarck Sea. Geol. Surv. Papua New Guinea, Mem. 7, 44 pp.

Sato, T., 1974. Distribution and geological setting of the Kuroko deposits. Soc. Min. Geol. Jpn. 6, 1-9.

Scutter, C.R., Cas, R.A.F., 1998. Pumiceous hyaloclastite, Ponza, Italy. IAVCEI Congr., Cape Town, July 1998, Abstr. 54.

Scutter, C.R., Cas, R.A.F., Moore, C.L., 1998. Facies architecture and origin of a submarine rhyolitic lava flow-dome couples, Ponza, Italy. J. Geophys. Res. 103, 27551-27566.

Siebert, L., 1984. Large volcanic debris avalanches: characteristics of source area, deposits, and associated eruptions. J. Volcanol. Geotherm. Res. 22, 163-197.

Tanimura, S., Date, J., Takahashi, T., Ohmoto, H., 1983. Part 
II. Stratigraphy and structure of the Hokuroku District. In: Ohmoto, H., Skinner, B.J. (Eds.), The Kuroko and Related Volcanogenic Massive Sulfide Deposits. Econ. Geol. Monogr. 5, 24-39.

Urabe, T., 1987. Kuroko deposit modelling based on magmatic hydrothermal theory. Miner. Geol. 37, 159-176.

Utada, M., 1970. Occurrence and distribution of authigenic zeolites in the Neogene pyroclastic rocks in Japan. General Education, Tokyo University, Scientific Paper 20, 191-262.

Walshe, J.L., Solomon, M., 1981. An investigation into the environment of formation of the volcanic-hosted Mt Lyell copper deposits using geology, mineralogy, stable isotopes and a six-component chlorite solid solution model. Econ. Geol. 76, 246-284.
Waters, J.C., Binns, R.A., 1998. Contrasting styles of felsic submarine volcanism, eastern Manus Basin, Papua New Guinea. 14th Aust. Geol. Convention, Townsville, July, Geol. Soc. Aust. Abstr. 49, p. 459.

Wohletz, K.H., 1983. Mechanisms of hydrovolcanic pyroclast formation: grain-size, scanning electron microscopy, and experimental studies. J. Volcanol. Geotherm. Res. 17, 31-63.

Yamagishi, H., 1991. Morphological and sedimentological characteristics of the Neogene submarine coherent lavas and hyaloclastites in Southwest Hokkaido, Japan. Sediment. Geol. 74, 5-23.

Yamagishi, H., 1987. Studies on the Neogene subaqueous lavas and hyaloclastites in Southwest Hokkaido. Rep. Geol. Surv. Hokkaido 59, 55-117. 